\title{
Diet and food consumption of a deep-sea fish, orange roughy Hoplostethus atlanticus (Pisces: Trachichthyidae), off southeastern Australia
}

\author{
C. M. Bulman, J. A. Koslow \\ CSIRO Division of Fisheries, GPO Box 1538, Hobart, Tasmania, 7001, Australia
}

\begin{abstract}
We examined the diet of nearly 7500 orange roughy Hoplostethus atlanticus Collett, 1889 from southeastern Australian waters caught during trawl surveys in 1988 and 1989. Juveniles fed mainly on bentho- and meso-pelagic crustaceans, while mature fish consumed predominantly fish and squid. The composition of the diet changed significantly with depth, geographical area, and year. Evidence of diel feeding periodicity found in adults at a station sampled over $42 \mathrm{~h}$ was supported by patterns of stomach fullness and digestion stage in the full data set. Based upon observed rates of stomach evacuation, daily rates of food consumption were estimated as $1.15 \%$ body weight for adults and $0.91 \%$ for juveniles. The metabolism of orange roughy, estimated from a mass balance model, is similar to that of active, migratory mesopelagic fishes and substantially higher than that of non-migratory bathypelagic fishes. The bodily composition of orange roughy, which is high in lipid and protein and low in water, is also similar to that of active mesopelagic fishes. Non-migratory bathypelagic fishes typically have exceptionally low metabolic rates, which, despite low food consumption, lead to high growth rates and high growth efficiency. Orange roughy, however, appears to have very high metabolic costs, which lead to an exceptionally low growth rate and growth efficiency, despite relatively high rates of food consumption.
\end{abstract}

\section{INTRODUCTION}

The food consumption and metabolism of deep-sea fishes have seldom been studied. There is particular interest in orange roughy Hoplostethus atlanticus Collett, 1889 because of the recent development of deepwater fisheries for this species off New Zealand and Australia. Orange roughy are found in the northeast Atlantic (Mauchline \& Gordon 1984), around the southern coast of South Africa to Madagascar and on the West Australian ridge in the Indian Ocean (Kotlyar 1980, Smith \& Heemstra 1986), but commercially significant quantities are not known from these regions. Studies in several parts of the world ocean (Kotlyar \& Lipskaya 1980, Mauchline \& Gordon 1984, Gordon \& Duncan 1987, Rosecchi et al. 1988) show consistently that orange roughy feed on bentho- and mesopelagic crustaceans, fish and squid. Crustaceans predominate in the diet of small orange roughy, and their diet shifts to fish as they grow (Rosecchi et al. 1988). Orange roughy seems to be an opportunistic, generalized benthopelagic predator similar to other fish at these depths (Mauchline \& Gordon 1986, Blaber \& Bulman 1987).
The food consumption and metabolism of orange roughy have not been studied. The species has not been maintained under laboratory conditions, and Rosecchi et al. (1988) found no evidence of diel periodicity in feeding, from which digestion rates may be estimated using stomach-content data from the field (Eggers 1977, Clarke 1978). Bathypelagic organisms generally consume less food than shallower species, possibly because their metabolism is lower rather than due to decreased growth rate (Torres et al. 1979, Childress et al. 1980, Mauchline 1988). However, orange roughy grows very slowly: validated otolith-based and radiometric aging studies indicate that orange roughy matures at about 20 yr at $\sim 30 \mathrm{~cm}$, and grows only 15 to $20 \mathrm{~cm}$ further over a life-span of 50 to $100+$ yr (Mace et al. 1990, Fenton et al. 1991). It might be expected, therefore, that orange roughy has a particularly low rate of food consumption, if its metabolism is similar to that of other non-migratory deepwater species.

Orange roughy is widely distributed in temperate Australian waters in depths from 700 to $1200 \mathrm{~m}$, where it is often the dominant species (Bulman et al. in press). This study of orange roughy feeding is based upon a large collection of stomachs (at least 10-fold more than 
previous studies of orange roughy feeding) that was obtained in southeastern Australian waters over two 5 mo field seasons.

Our objectives in this study were: (1) to describe the diet of orange roughy in Australian waters in relation to area, depth, size, and year; and (2) to examine the food consumption and metabolism of orange roughy based upon an analysis of diel feeding periodicity and digestion rate.

\section{MATERIALS AND METHODS}

Field collection. In 1988 and 1989, an area of about $13000 \mathrm{~km}^{2}$ off southeastern Australia was surveyed by FRV 'Soela', using an Engel high-lift trawl (Fig. 1). The survey was based on a random depth-stratified design consisting of $100 \mathrm{~m}$ depth strata from 700 to $1200 \mathrm{~m}$ in 1988 and 800 to $1200 \mathrm{~m}$ in 1989 . Cruises were undertaken from January to May in both years. The number of valid stations at which orange roughy were caught was 162 in 1988 and 167 in 1989. The survey area was divided into subareas corresponding to broad geographical regions: Great Australian Bight (GAB), western Tasmania and western Bass Strait (WTas), eastern Tasmania (ETas), eastern Bass Strait (EBass), and in 1988, New South Wales (NSW) (Fig. 1). A site off NSW was sampled at regular intervals over $82 \mathrm{~h}$ to obtain data on diel feeding periodicity, but sufficient adult orange roughy were obtained only for the first $42 \mathrm{~h}$.
Laboratory analysis. The stomachs of up to 40 orange roughy from each tow were examined in the 1988 survey and 20 per tow in the 1989 survey. The whole stomach was assessed for digestion as being either at an early (stage 1) or late (stage 2) stage of digestion. Prey items were identified to species or genus where possible, and weighed after excess moisture had been removed.

Data analysis. The numbers in many prey categories were too low to permit statistical analysis, so prey items were grouped into more general taxa [sergestids, pasiphaeids, oplophorids, mysids, amphipods, other Crustacea (mostly unidentified), fish, squid and other prey (miscellaneous)]. The percentage of the total weight of the prey and the frequency of occurrence of prey items in stomachs containing food were calculated for each prey category. Stomach fullness for each tow ( $g \mathrm{~kg}^{-1}$ ) was calculated by dividing the summed weight of prey items in all the stomachs by the weight of all fish examined.

The data were analysed separately by subarea, depth, year, and length. In all analyses except by length, data from fish $>30 \mathrm{~cm}$ (the mean size at maturity) and fish $\leq 30 \mathrm{~cm}$ were analysed separately. The number of tows in the EBass area in 1989 was too small to compare with the 1988 results and there were no NSW data in 1989. Consequently only data from GAB, WTas and ETas in both years were analysed. Data from tows within aggregations of orange roughy (i.e. large concentrations that were recognizable both acousti-

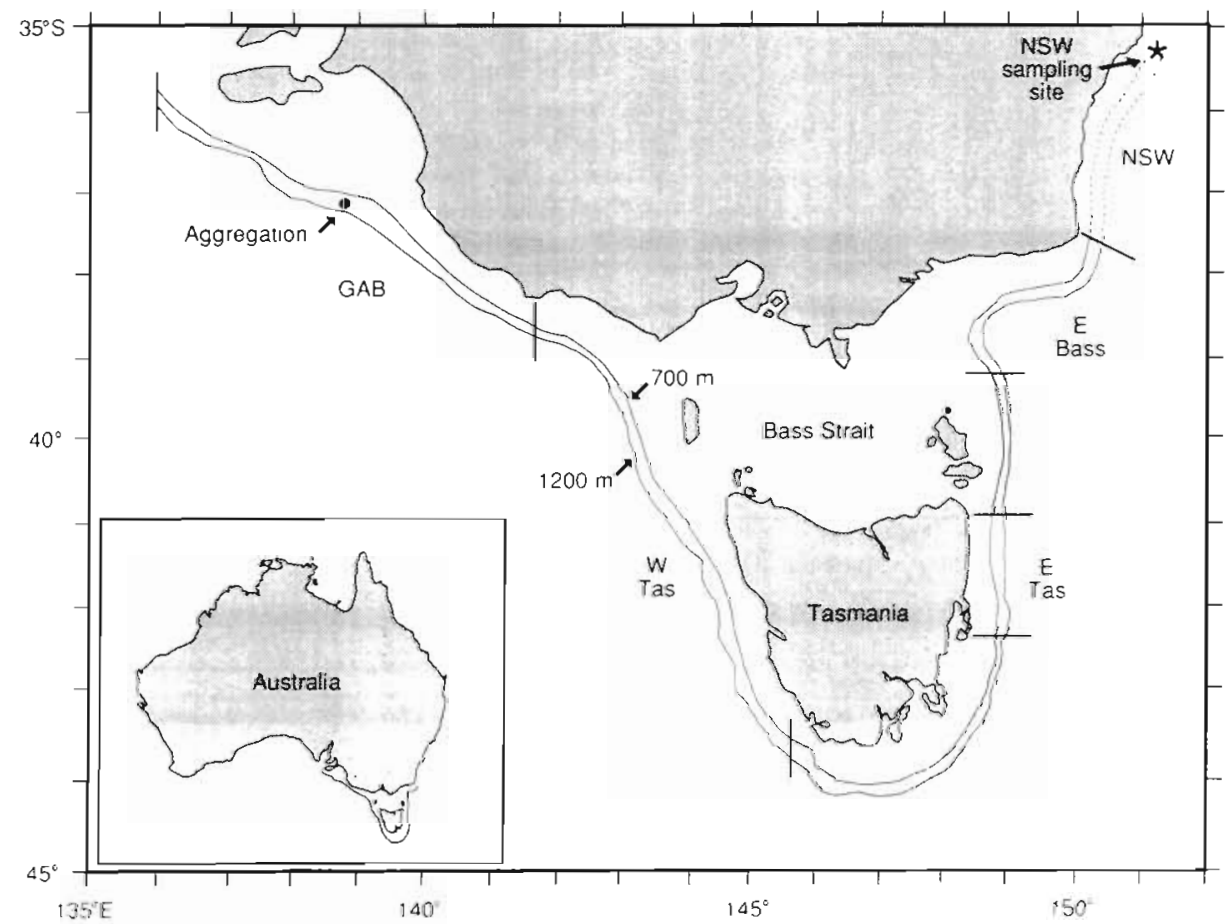

Fig. 1. Survey area off southeastern Australia showing the 700 and $1200 \mathrm{~m}$ depth contours, boundaries of the regional survey strata, and location of the orange roughy Hoplostethus atlanticus aggregation. The shaded areas represent untrawlable grounds, which were not surveyed. The NSW sampling station is indicated by $\star$. GAB = Great Australian Bight; WTas $=$ West Tasmania and Bass Strait; ETas = East Tasmania $;$ EBass = East Bass Strait; NSW $=$ New South Wales 
cally and from the trawls) were compared with data from the rest of the subarea.

The overall similarity of diets from different areas was tested with Kendall's coefficient of concordance, $W$ (Tate \& Clelland 1957), a nonparametric ranking test and Friedman's rank 2-way classification, $T$ (Conover 1971). More detailed analyses of variation in diet in relation to fish size, depth, year, subarea, and aggregation were conducted with contingency-table analyses or logistic regression, based upon the frequency of occurrence of different prey items in the stomachs. The prey items were grouped into major sub-categories (crustaceans, fish, squid) in carrying out more complex statistical analyses.

Two types of data were used to investigate diel periodicity of feeding. Mean stomach fullness per tow and the proportions of stomachs at each digestion stage were each averaged per $4 \mathrm{~h}$ interval. Digestion stages 1 and 2 were combined because of low numbers in both stages, and stages 3 and 4 were combined, since both indicated late stages of digestion and were apparently reached many hours after intake. These data were plotted and contingency analyses carried out to test for differences between time periods. Analyses were carried out on both the full data set and that of the $82 \mathrm{~h}$ station off NSW.

Mean daily food consumption ( $C$ ) was estimated from data for mean stomach fullness per tow obtained at the single station off NSW. The method of Eggers (1977, 1979) was used, because it appears more robust for use with field data than the method of Elliott \& Persson (1978), particularly when digestion rate cannot be determined in the laboratory (Boisclair \& Leggett 1988):

$$
C=24 \times S \times R
$$

where $S=$ mean stomach fullness ( $\mathrm{g} \mathrm{kg}^{-1}$ body weight) over $24 \mathrm{~h}$, and $R=$ digestion rate per hour $R$ is determined from the apparent rate of food evacuation, based upon diel differences in stomach fullness:

$$
S_{t}=S_{0} \mathrm{e}-R_{t}
$$

where $t=$ time. Using the natural logarithmic transformation of Eq. (2), $R$ was estimated by linear regression analysis.

$$
\ln \left(S_{\mathrm{t}}\right)=\ln \left(S_{0}\right)-R_{t}
$$

Empty stomachs were omitted from this analysis, because empty stomachs bias estimates of evacuation rate, since the time of emptying is not known (Olson \& Mullen 1986). However, our estimate of digestion rate and food consumption will have a conservative bias if the orange roughy do not entirely cease feeding during the period of greatest decline in mean stomach fullness.

\section{RESULTS}

\section{Diet}

A total of 7486 stomachs was examined, 4573 from 1988 and 2913 from 1989. Of this total, $41 \%$ of stomachs (3049) contained food (45\% from 1988 and $34 \%$ from 1989). The diet of orange roughy in southeastern Australian waters was found to consist of natant decapods, mysids, amphipods, benthopelagic fish and squid (see Tables 2 to 5; Fig. 2). Acanthephyra pelagica and an unidentified species of Pasiphae were the most common carid prawns found, and Sergestes (Sergestes) arcticus was the predominant penaeid. Gnathophausia sp. was the largest mysid identified; smaller mysid specimens were difficult to identify but were probably Boreomysis sp. (B. Griffiths, CSIRO, pers. comm.). Two species of amphipods from the family Lyssianassidae were identified: Eurythenes grillus and Trischizostoma nicaeense. Most fish were unidentifiable, but Chauliodus sloani was easily identified even in advanced stages of digestion because the jaws of this species are distinctive and were digested at a slower rate than the rest of the fish. Myctophids were common in orange roughy stomachs but in their halfdigested state could not always be identified further. However, Lampanyctus spp. and Lampichthys spp. were identified and most of the unidentified myctophids were thought to be from these genera. The rapid deterioration of squid made identification impossible, but some beaks from the families Onychoteuthidae, Histioteuthidae, Cranchiidae and Brachioteuthidae were identified.

\section{Changes in diet with size and depth}

The diet shifted from predominantly Crustacea in the smaller orange roughy to fish in the larger animals (Fig. 3). Squid became important in the diet of orange roughy greater than $20 \mathrm{~cm}$, comprising 15 to $20 \%$ of prey weight.

The frequency with which crustaceans and fish were eaten by orange roughy varied significantly with depth (Fig. 4). The effect of depth varied both in the 2 years of the study and with different size groups of orange roughy (Table 1). However, the effect of size became consistent when juveniles and adults were separated for analysis: size was always a significant effect in immature but not in mature size-classes.

Depth-related changes in the diet of mature orange roughy were often inversely related to those of immature fish (Fig. 4). Crustaceans occurred least frequently in the diet of immature orange roughy at a minimum of $900 \mathrm{~m}$ in 1988 (Fig. 4a) and at 900 to $1000 \mathrm{~m}$ in 1989 (Fig. 4 b) but became more frequent in deeper water, 
(a) Juveniles

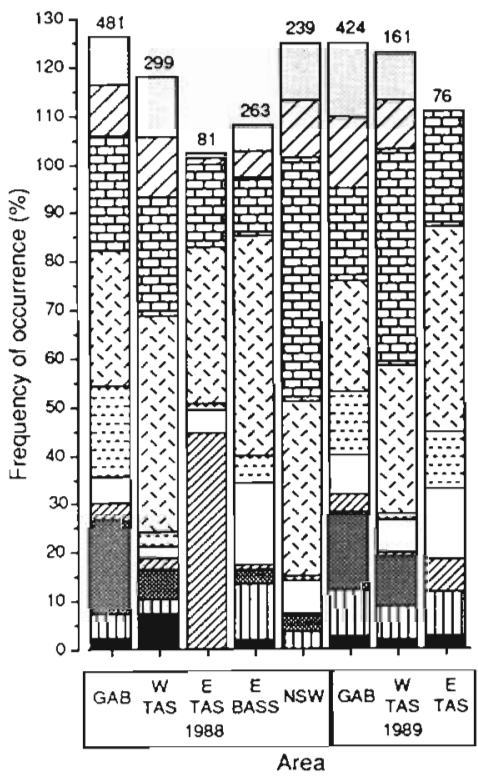

(c) Adults

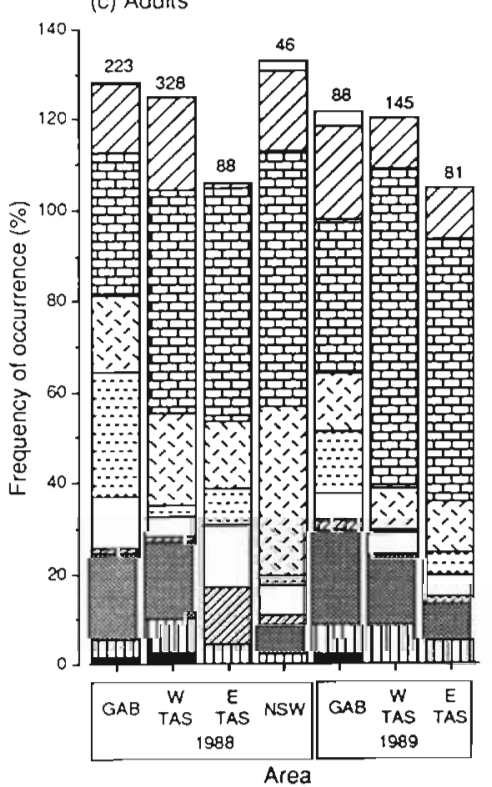

(b) Juveniles

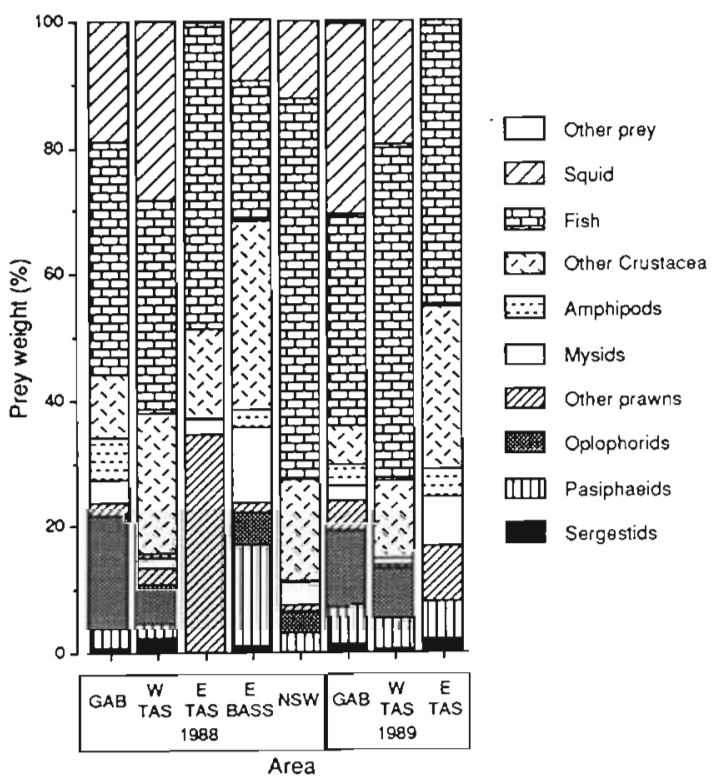

(d) Adults

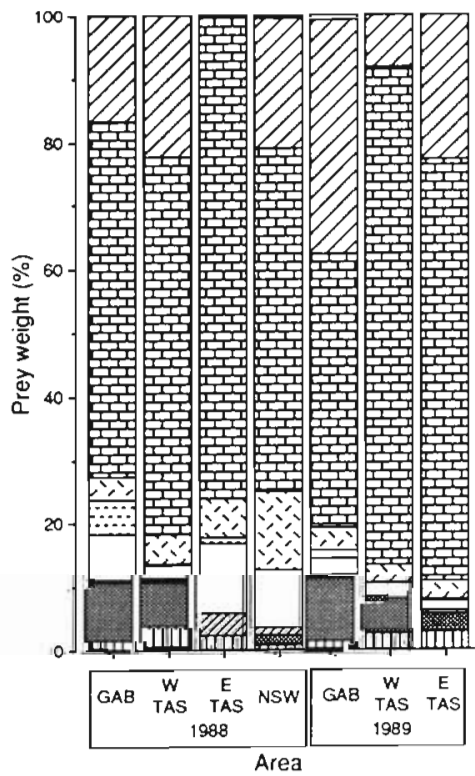

Fig. 2. Hoplostethus atlanticus. Dietary composition by sampling region based upon $(a, c)$ frequency of occurrence and $(b, d)$ total prey weight, for $(a, b)$ juveniles $(\leq 30 \mathrm{~cm} \mathrm{SL})$ and $(c, d)$ adults $(>30 \mathrm{~cm}$ SL) whereas crustaceans in the adult diet peaked at $800 \mathrm{~m}$ depth in 1988 and at $900 \mathrm{~m}$ in 1989 and then declined in deeper water. In contrast, fish were most frequent in juvenile orange roughy at a depth of $900 \mathrm{~m}$ in 1988 (Fig. 4c) and at around 900 to $1000 \mathrm{~m}$ in 1989 (Fig. 4d) and then declined in deeper water. Fish were least common in the largest orange roughy $(\geq 35 \mathrm{~cm})$ at $900 \mathrm{~m}$ but increased significantly in both years at deeper depths (Fig. 4c, d; Table 1). Both mature sizeclasses fed to a greater extent on fish and less on crustaceans in 1989 [year $\times$ depth (adults): Table 1] than in 1988 . The frequency with which squid occurred in the diet of orange roughy (Fig. 4e, f) did not vary significantly with depth, but the larger immature fish ate proportionately more squid than the smaller classes.

\section{Regional and interannual differences in diet}

The rank order of prey categories in the diet of orange roughy did not differ significantly throughout the survey area and between years, based upon analysis of frequency of occurrence data ( $W$ (adults) $=0.695$, $T=58.25, \mathrm{p}<0.005 ; W$ (juveniles) $=0.859, T=69.58$, 


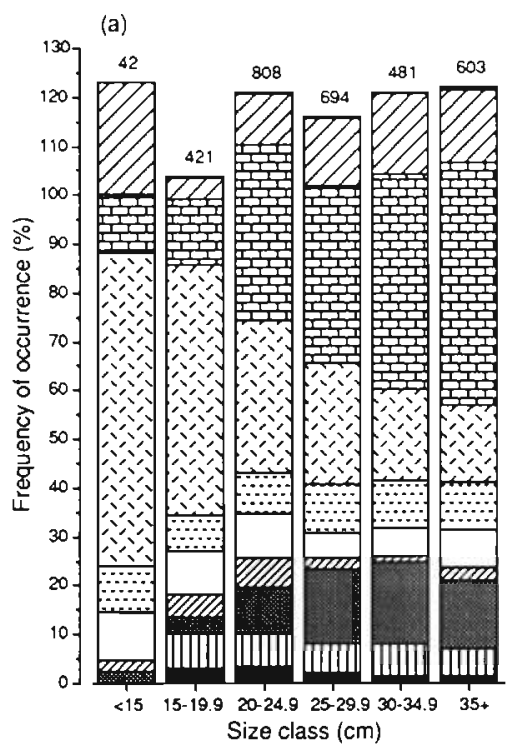

(b)

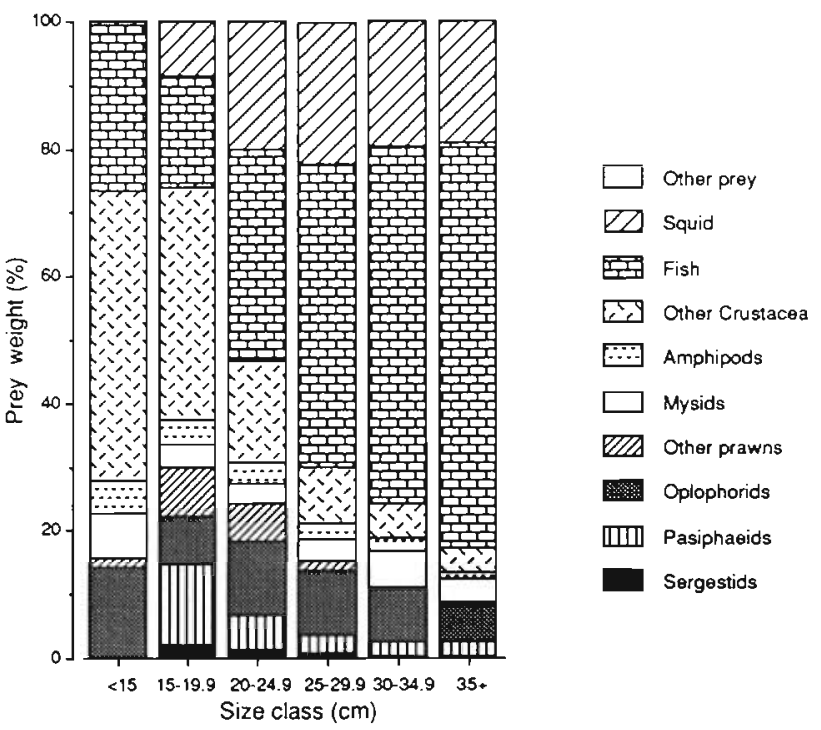

Fig. 3. Hoplostethus atlanticus. Dietary composition of size classes by (a) frequency of occurrence and (b) percentage of total prey weight
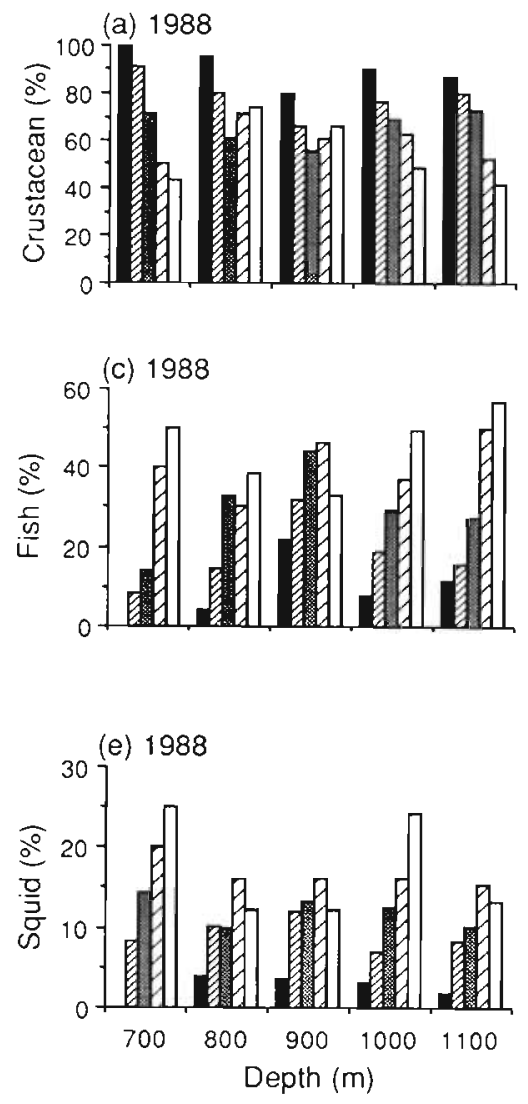

Fig. 4. Hoplostethus atlanticus. Proportions of prey in the diet by depth, size, and year: consumption of crustaceans in (a) 1988 and (b) 1989; consumption of fish in (c) 1988 and (d) 1989; consumption of squid in (e) 1988 and (f) 1989

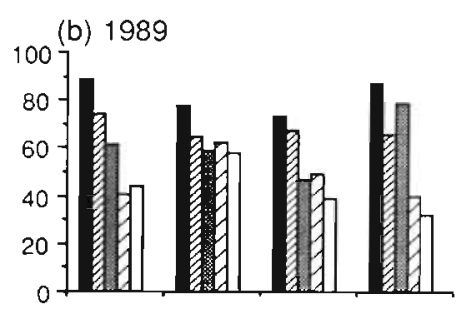

(d) 1989
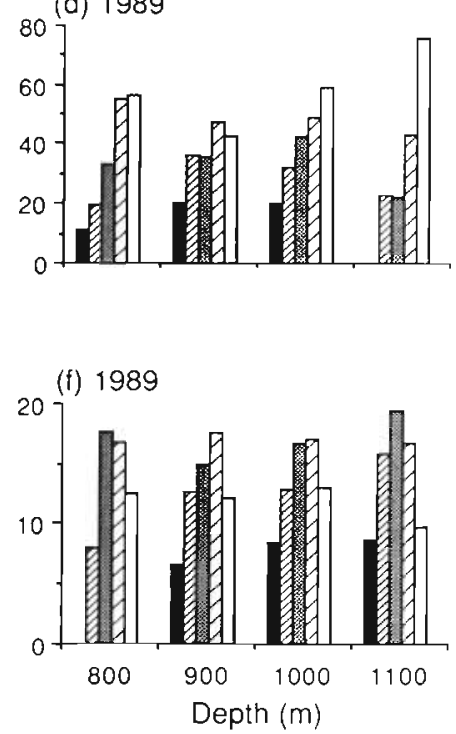

$<20 \mathrm{~cm} 20-24.9 \mathrm{~cm} 25-29.9 \mathrm{~cm} \quad 30-34.9 \mathrm{~cm}$ - $>35 \mathrm{~cm}$

Immature fish

The incidence of feeding in immature fish was sig-

nificantly higher in $1988(43.2 \%)$ than in $1989(35.1 \%)$ $\mathrm{p}<0.005]$ or prey weight $[W$ (adults) $=0.892, T=$ 64.22, $\mathrm{p}<0.005 ; W$ (juveniles) $=0.713, T=57.79$, $\mathrm{p}<0.005]$. However, there were significant differences in the actual proportions of some prey categories. 
Table 1. Hoplostethus atlanticus. Significant chi-squared statistics from 4-way contingency table analyses to determine the relationship between occurrence of prey, depth of capture, size of orange roughy and year

\begin{tabular}{|c|c|c|c|}
\hline $\begin{array}{l}\text { Prey } \\
\text { Effect }\end{array}$ & $\begin{array}{l}\text { All data } \\
\chi^{2}, \mathrm{df}, \mathrm{p}\end{array}$ & $\begin{array}{c}\text { Juveniles } \\
\chi^{2}, \mathrm{df}, \mathrm{p}\end{array}$ & $\begin{array}{c}\text { Adults } \\
\chi^{2}, \mathrm{df}, \mathrm{p}\end{array}$ \\
\hline \multicolumn{4}{|l|}{ Crustacea } \\
\hline $\begin{array}{l}\text { Depth } \times \text { Size } \\
\text { Year } \times \text { Depth } \\
\text { Size }\end{array}$ & $\begin{array}{l}51.32,12, \cdots \\
10.04, \quad 3,\end{array}$ & $\begin{array}{c}8.03,3,{ }^{\circ} \\
69.92,2, \cdots\end{array}$ & $9.17,3^{\circ}$ \\
\hline \multicolumn{4}{|l|}{ Fish } \\
\hline $\begin{array}{l}\text { Depth } \times \text { Size } \\
\text { Year } \times \text { Depth } \\
\text { Year } \\
\text { Size }\end{array}$ & $\begin{array}{c}54.35,12, \cdots \\
9.20,3,\end{array}$ & $\begin{array}{c}8.95,3, \\
66.88,2, \cdots\end{array}$ & $\begin{array}{l}12.65,3, \cdots \\
11.77,1, \cdots\end{array}$ \\
\hline $\begin{array}{l}\text { Squid } \\
\text { Year } \\
\text { Size }\end{array}$ & $45.49, \quad 4, \cdots$ & $\begin{array}{r}4.37,1 \\
28.95,2, \cdots\end{array}$ & \\
\hline $0.01<\mathrm{p}<0.05 ; \cdots$ & & & \\
\hline
\end{tabular}

(Pearson's $\left.\chi^{2}(1)=31.73, \mathrm{p}<0.005\right)$; and mean stomach fullness was $79 \%$ higher in 1988 (Tables 2 \& 3 ). Crustaceans constituted a large proportion of their diet: about $50 \%$ by weight in 1988 and $40 \%$ in 1989 (Fig. 2a, b).

Amphipods occurred with variable frequency but were most common in the GAB samples in 1988 (time $x$ area: $\left.\chi_{(2)}^{2}=12.24, p<0.005\right)$. Pasiphaeids and mysids were found more frequently in $1989\left(\chi^{2}(1)=14.86, \mathrm{p}<\right.$ 0.001 and $\chi_{(1)}^{2}=10.34, \mathrm{p}<0.005$ respectively) and oplophorids were more frequent in GAB fish (area: $\chi^{2}{ }_{(2)}$ $=75.51, \mathrm{p}<0.001)$. Juveniles in WTas in 1989 ate fish most frequently (time $\times$ area: $\chi^{2}(2)=21.17, p<0.001$ ). Juveniles on the east coast of Tasmania did not eat squid, but there were no differences in its consumption in the other 2 areas.

Adults

The incidence of feeding in mature size-classes was, as in juveniles, higher in $1988(48.9 \%)$ than in 1989 $(32.0 \%)$ (Pearson's $\left.\chi_{(1)}^{2}=67.75, p<0.005\right)$, and mean stomach fullness was $61 \%$ higher in 1988 (Tables 4, 5).

Only a few regional differences in diet were significant. Amphipods were twice as common in stomachs in 1988 than in $1989\left(\chi^{2}(1)=9.69, p<0.01\right)$ and also occurred in stomachs of fish from the GAB 4 to 10 times more frequently than anywhere else $\left(\chi^{2}(2)=94.16, p<\right.$ $0.01)$. Mysids were less frequent on the west coast of Tasmania than in the GAB or east Tasmania $\left(\chi^{2}(2)=\right.$ $10.42, p<0.01$ ). The occurrence of fish in stomachs varied significantly but exhibited no consistent patterns (time $\times$ area: $\chi^{2}{ }_{(2)}=6.03, p<0.05$ ), fish were most frequent in 1989 stomachs in WTas. The occurrence of squid also varied with time and area $\left(\chi_{(2)}^{2}=14.56, p<\right.$
$0.01)$, but the greatest proportion of fish eating squid occurred in the GAB in 1989, and the least in ETas.

\section{Diet within aggregations}

An aggregation of orange roughy consisting wholly of adult fish was sampled in the GAB in 1988. The incidence of feeding was significantly higher in the aggregation $(69 \%)$ than in adult fish from the rest of the GAB area $\left(52 \%\right.$ ) (Pearson's $\chi^{2}(1)=8.53, p<0.005$ ). However, the mean stomach fullness $( \pm \mathrm{SE})$ of the 3 tows in the aggregation $\left(6.6 \pm 1.8 \mathrm{~g} \mathrm{~kg}^{-1}\right)$ was not significantly different ( $t$-test, $t_{(48)}=9.349$ ) to that of the rest of the GAB tows $\left(5.9 \pm 1.3 \mathrm{~g} \mathrm{~kg}^{-1}\right)$. Amphipods occurred significantly more frequently in fish from the aggregation than in 'non-aggregation' fish (Pearson's $\chi_{(1)}^{2}=13.46, p=0.002$ ), but pasiphaeids occurred significantly less often (Fisher's Exact test, $p=0.003$ ) (Fig. 5). Fish sampled from a small aggregation off east Tasmania in 1989 were not different from fish from the rest of the region in either incidence of prey or stomach fullness.

\section{Diel feeding periodicity}

Periodicity in stomach fullness

Data collected at a single site off NSW over $42 \mathrm{~h}$ indicated that mean stomach fulness of adult orange roughy peaked in the middle of the night, after which it declined steadily until midday or evening (Fig. 6). Based upon the mean of the rates of decline in stomach fullness measured over each of 3 days, the instantane- 
Table 2. Hoplostethus atlanticus. Percentage of total prey weight $(\% \mathrm{~W})$ and frequency of occurrence $(\% \mathrm{~F})$ of prey items in the diet of juveniles during 1988. See Fig. 1 for abbreviations of sampling areas

\begin{tabular}{|c|c|c|c|c|c|c|c|c|c|c|c|c|}
\hline \multirow[t]{2}{*}{ Prey species } & \multicolumn{2}{|c|}{ GAB } & \multicolumn{2}{|c|}{ WTas } & \multicolumn{2}{|c|}{ ETàs } & \multicolumn{2}{|c|}{ EBass } & \multicolumn{2}{|c|}{ NSW } & \multicolumn{2}{|c|}{ Total } \\
\hline & $\% W$ & $\% \mathrm{~F}$ & $\% \mathrm{~W}$ & $\% \mathrm{~F}$ & $\% \mathrm{~W}$ & $\% F$ & $\% \mathrm{~W}$ & $\% \mathrm{~F}$ & $\% W$ & $\% \mathrm{~F}$ & $\% \mathrm{~W}$ & $\% \mathrm{~F}$ \\
\hline \multicolumn{13}{|l|}{ Crustacea } \\
\hline Unidentified & 10.3 & 27.9 & 22.2 & 44.8 & 12.1 & 30.9 & 29.7 & 45.2 & 15.9 & 36.0 & 16.0 & 36.5 \\
\hline Copepoda & 0 & 0 & 0 & 0 & 1.9 & 1.2 & 0 & 0 & 0 & 0 & 0.1 & 0.1 \\
\hline \multicolumn{13}{|l|}{ Mysidacea } \\
\hline Unidentified & 2.2 & 5.0 & 1.7 & 2.3 & 1.8 & 3.7 & 5.1 & 14.4 & 2.3 & 5.4 & 2.3 & 6.2 \\
\hline Gnathophausia sp. & 1.2 & 0.2 & 0 & 0 & 0.5 & 1.2 & 6.7 & 2.3 & 1.2 & 1.3 & 1.4 & 0.8 \\
\hline Amphipoda & 6.7 & 18.7 & 0.7 & 3.0 & 0.4 & 1.2 & 3.0 & 5.7 & 0.3 & 0.8 & 3.4 & 8.6 \\
\hline \multicolumn{13}{|l|}{ Decapoda } \\
\hline \multicolumn{13}{|l|}{ Penaidae } \\
\hline Unidentified & 0.2 & 0.8 & 0.1 & 0.3 & 11.4 & 6.2 & 0 & 0 & 0 & 0 & 0.7 & 0.7 \\
\hline Sergestes (Sergestes) arcticus & 0.7 & 2.3 & 2.4 & 7.4 & 0 & 0 & 1.1 & 1.9 & 0 & 0 & 1.0 & 2.8 \\
\hline \multicolumn{13}{|c|}{ Caridae } \\
\hline Unidentified & 1.5 & 3.1 & 2.5 & 2.0 & 23.2 & 38.3 & 1.5 & 1.1 & 1.1 & 0.4 & 2.8 & 4.0 \\
\hline Pasiphae spp. & 3.2 & 5.0 & 2.4 & 3.0 & 0 & 0 & 15.8 & 11.4 & 3.2 & 3.8 & 4.0 & 5.3 \\
\hline Acanthephyra pelagica & 16.9 & 18.3 & 5.9 & 6.0 & 0 & 0 & 5.2 & 3.0 & 3.3 & 3.3 & 9.8 & 9.0 \\
\hline Oplophorus novaezelandiae & 1.2 & 1.0 & 0 & 0 & 0 & 0 & 0 & 0 & 0 & 0 & 0.5 & 0.4 \\
\hline \multicolumn{13}{|l|}{ Pisces } \\
\hline Unidentified & 26.5 & 20.8 & 24.2 & 21.1 & 19.9 & 6.2 & 17.0 & 10.6 & 50.6 & 45.6 & 29.2 & 22.4 \\
\hline Gonostomatidae & 4.6 & 0.8 & 1.2 & 0.3 & 0 & 0 & 0 & 0 & 0 & 0 & 2.3 & 0.4 \\
\hline \multicolumn{13}{|l|}{ Chauliodontidae } \\
\hline Chauliodus sloani & 1.9 & 0.6 & 0.8 & 0.3 & 0 & 0 & 3.8 & 0.4 & 2.7 & 0.4 & 1.9 & 0.4 \\
\hline \multicolumn{13}{|l|}{ Myctophidae } \\
\hline Unidentified & 1.7 & 0.8 & 5.8 & 1.7 & 2.2 & 1.2 & 1.4 & 1.1 & 0 & 0 & 3.7 & 1.7 \\
\hline Lampanyctus spp. & 1.6 & 0.6 & 1.6 & 0.7 & 0 & 0 & 0 & 0 & 0 & 0 & 1.1 & 0.4 \\
\hline Lampichthys sp. & 0 & 0 & 0.2 & 0.3 & 6.7 & 2.5 & 0 & 0 & 7.1 & 4.2 & 0.4 & 0.2 \\
\hline \multicolumn{13}{|l|}{ Macrouridae } \\
\hline Coryphaenoides spp. & 0.3 & 0.2 & 0 & 0 & 0 & 0 & 0 & 0 & 0 & 0 & 0.1 & 0.1 \\
\hline \multicolumn{13}{|l|}{ Apogonidae } \\
\hline Epigonus lenimen & 0 & 0 & 0 & 0 & 19.9 & 7.4 & 0 & 0 & 0 & 0 & 1.0 & 0.4 \\
\hline \multicolumn{13}{|l|}{ Mollusca } \\
\hline Cephalopoda & 19.2 & 10.2 & 28.3 & 12.4 & 0.1 & 1.2 & 9.8 & 5.3 & 12.3 & 11.7 & 18.3 & 9.5 \\
\hline Total weight of prey $(\mathrm{g})$ & \multicolumn{2}{|c|}{3359.8} & \multicolumn{2}{|c|}{1850.9} & \multicolumn{2}{|c|}{406.0} & \multicolumn{2}{|c|}{688.6} & \multicolumn{2}{|c|}{1443.7} & 77 & 9.0 \\
\hline Total stomachs examined & & & & & & & 6 & & & & & \\
\hline Stomachs with food present $(\%)$ & 481 & 12.3) & 299 & (6.0) & 811 & 8.2) & 263 & $39.1)$ & 239 & 15.4) & 1363 & 43.2) \\
\hline Mean of average stomach fullness & & & & & & & & & & & & \\
\hline per tow $\left(\mathrm{g} \mathrm{kg}^{-1}\right)$ & 5.16 & 4.73 & 6.67 & 6.56 & $4.07=$ & 3.93 & $2.96=$ & $=1.83$ & 3.86 & 2.03 & 5.02 & 4.80 \\
\hline No. of tows & & & & & 1 & & 2 & & & & & \\
\hline
\end{tabular}

ous hourly digestion rate $(R)$ was estimated to be 0.097 $\mathrm{h}^{-1}$ (Fig. 6). There was supporting evidence of diel periodicity in the full data set, although the pattern was not quite significant (Fig. $7 a$; Kruskal-Wallis test: $\chi^{2}{ }_{(272)}$ $=10.68, \mathrm{p}=0.056)$.

The data for stomach fullness for juveniles at this station were more variable, and no significant pattern was observed for this station or for the whole data set (Fig. 7b).

\section{Periodicity in digestion stage}

Although a significant diel pattern of stomach fullness was not observed in juvenile orange roughy, the juveniles showed significant diel differences in the digestion stage of the stomach contents (Fig. 8) (juveni- les: $\left.\chi_{(10)}^{2}=30.97, p<0.001\right)$. The highest proportions with food in the early stages of digestion were observed in the afternoon and evening (12:00 to 20:00 h), while the highest proportion of stomachs with food in the later stages of digestion was obtained in the morning (08:00 to $12: 00 \mathrm{~h}$ ). These results are consistent with a pattern of feeding in the afternoon and first half of the night, with little feeding from midnight to midday. However, it should be noted that over $50 \%$ of juvenile and adult roughy stomachs were empty at all times, and the highest proportion of stomachs containing food were consistently in the most advanced stage of digestion. The lack of clearer diel patterns in the full data set is not surprising, considering that the depths, areas and time periods of the study were combined for our analysis. 
Table 3. Hoplostethus atlanticus. Percentage of total prey weight ( $\% \mathrm{~W})$ and frequency of occurrence $(\% \mathrm{~F})$ of prey items in the diet of juveniles during 1989. See Fig. 1 for abbreviations of sampling areas

\begin{tabular}{|c|c|c|c|c|c|c|c|c|c|c|}
\hline \multirow[t]{2}{*}{ Prey species } & \multicolumn{2}{|c|}{ GAB } & \multicolumn{2}{|c|}{ WTas } & \multicolumn{2}{|c|}{ ETas } & \multicolumn{2}{|c|}{ EBass } & \multicolumn{2}{|c|}{ Total } \\
\hline & $\% \mathrm{~W}$ & $\% F$ & $\% W$ & $\% \mathrm{~F}$ & $\% \mathrm{~W}$ & $\% \mathrm{~F}$ & $\% \mathrm{~W}$ & $\% \mathrm{~F}$ & $\% W$ & $\% \mathrm{~F}$ \\
\hline Polychaeta & 0.1 & 0.5 & 0 & 0 & 0 & 0 & 0 & 0 & 0.1 & 0.3 \\
\hline \multicolumn{11}{|l|}{ Crustacea } \\
\hline Unidentified & 6.2 & 22.9 & 11.7 & 30.4 & 25.7 & 42.1 & 7.3 & 27.8 & 8.7 & 27.0 \\
\hline \multicolumn{11}{|l|}{ Mysidacea } \\
\hline Unidentified & 1.4 & 6.8 & 0.9 & 6.8 & 5.2 & 13.2 & 0 & 0 & 1.3 & 7.4 \\
\hline Gnathophausia sp. & 1.0 & 1.2 & 0 & 0 & 2.6 & 1.3 & 0 & 0 & 0.8 & 0.9 \\
\hline Amphipoda & 3.3 & 13.0 & 0.1 & 1.2 & 4.3 & 11.8 & 0 & 0 & 2.3 & 9.7 \\
\hline \multicolumn{11}{|l|}{ Decapoda } \\
\hline \multicolumn{11}{|l|}{ Penaidae } \\
\hline Unidentified & 0 & 0 & 0 & 0 & 4.2 & 1.3 & 0 & 0 & 0.2 & 0.1 \\
\hline Plesiopenaeus edwardsianus & 0.8 & 0.2 & 0 & 0 & 0 & 0 & 0 & 0 & 0.5 & 0.1 \\
\hline Sergestes (Sergestes) arcticus & 1.4 & 2.6 & 0.4 & 1.9 & 2.1 & 2.6 & 0 & 0 & 1.1 & 2.4 \\
\hline \multicolumn{11}{|l|}{ Caridae } \\
\hline Unidentified & 1.3 & 2.1 & 0.6 & 0.6 & 4.7 & 5.3 & 0 & 0 & 1.2 & 2.1 \\
\hline Pasiphae spp. & 6.1 & 9.4 & 5.1 & 6.8 & 5.8 & 9.2 & 0.6 & 5.6 & 5.6 & 8.7 \\
\hline Acanthephyra pelagica & 10.5 & 13.9 & 3.5 & 4.3 & 0 & 0 & 0 & 0 & 7.6 & 9.7 \\
\hline A. quadrispinosa & 0.9 & 1.7 & 4.6 & 5.6 & 0 & 0 & 0 & 0 & 1.9 & 2.4 \\
\hline Oplophorus novaezelandiae & 0.7 & 0.5 & 0 & 0 & 0 & 0 & 0 & 0 & 0.5 & 0.3 \\
\hline Plesionika martia & 0.4 & 0.2 & 0 & 0 & 0 & 0 & 0 & 0 & 0.3 & 0.1 \\
\hline Lipkius holthuisi & 1.7 & 0.9 & 0.1 & 0.6 & 0 & 0 & 0 & 0 & 1.1 & 0.7 \\
\hline Nematocarcinus sigmoideus & 0.2 & 0.2 & 0 & 0 & 0 & 0 & 0 & 0 & 0.1 & 0.1 \\
\hline \multicolumn{11}{|l|}{ Pisces } \\
\hline Unidentified & 17.8 & 14.4 & 40.7 & 35.4 & 26.1 & 19.7 & 48.4 & 38.9 & 25.8 & 20.6 \\
\hline Gonostomatidae & 3.6 & 0.7 & 1.7 & 1.9 & 0 & 0 & 0 & 0 & 2.7 & 0.9 \\
\hline \multicolumn{11}{|l|}{ Neoscopelidae } \\
\hline Neoscopelus sp. & 1.0 & 0.2 & 0 & 0 & 0 & 0 & 0 & 0 & 0.7 & 0.1 \\
\hline \multicolumn{11}{|l|}{ Chauliodontidae } \\
\hline Chauliodus sloani & 3.9 & 0.9 & 1.8 & 1.2 & 0 & 0 & 0 & 0 & 3.0 & 0.9 \\
\hline \multicolumn{11}{|l|}{ Myctophidae } \\
\hline Unidentified & 0 & 0 & 1.0 & 1.9 & 0 & 0 & 0 & 0 & 0.3 & 0.4 \\
\hline Lampanyctus spp. & 0.1 & 0.2 & 3.5 & 1.9 & 19.3 & 3.9 & 10.3 & 5.6 & 2.4 & 1.2 \\
\hline Bathylagidae & 1.3 & 0.5 & 1.1 & 0.6 & 0 & 0 & 0 & 0 & 1.1 & 0.4 \\
\hline \multicolumn{11}{|l|}{ Macrouridae } \\
\hline Coryphaenoides spp. & 0 & 0 & 2.9 & 0.6 & 0 & 0 & 0 & 0 & 0.8 & 0.1 \\
\hline Other fish & 5.8 & 2.1 & 0.7 & 1.2 & 0 & 0 & 0 & 0 & 3.8 & 1.6 \\
\hline \multicolumn{11}{|l|}{ Mollusca } \\
\hline Cephalopoda & 30.3 & 14.9 & 19.5 & 9.9 & 0 & 0 & 33.4 & 27.8 & 25.9 & 12.4 \\
\hline \multicolumn{11}{|l|}{ Tunicata } \\
\hline Pyrosoma sp. & 0.4 & 0.9 & 0 & 0 & 0 & 0 & 0 & 0 & 0.3 & 0.6 \\
\hline Total weight of prey & \multicolumn{2}{|c|}{2508.7} & \multicolumn{2}{|c|}{1100.8} & \multicolumn{2}{|c|}{191.3} & & & & \\
\hline Total stomachs examined & & & & & & & & & & \\
\hline Stomachs with food present $(\%)$ & 424 & $0.4)$ & 1641 & 25.0) & 76 & 2.0) & 18 & 2.1) & 679 & 35.1) \\
\hline Mean of average stomach fullness & 524 & 578 & 361 & 361 & 216 & 1.72 & 6.99 & 2.72 & 2.81 & 2.47 \\
\hline No. of tows & $0.2 \times$ & & $\theta$ & & & & & & & \\
\hline
\end{tabular}

\section{Food consumption}

Based upon our estimate of $R$ and the mean stomach fullness (4.94 $\mathrm{g} \mathrm{kg}^{-1}$ for adults; Tables 4, 5), orange roughy were estimated to consume $11.50 \mathrm{~g} \mathrm{~kg}^{-1} \quad(=$ $1.15 \%$ body wt) over the $24 \mathrm{~h}$ day. The digestion rate of juveniles was not estimated separately. However, their mean stomach fullness was similar to that of the adults (3.90 $\mathrm{g} \mathrm{kg}^{-1}$ body wt) (Tables 2,3), and if the same digestion rate is assumed, their daily food consumption may be estimated to be $9.08 \mathrm{~g} \mathrm{~kg}^{-1}$ (=0.91\% body wt).

\section{DISCUSSION}

The results of our dietary analyses of Australian Hoplostethus atlanticus are consistent with those obtained elsewhere in the species' geographical range. $H$. atlanticus feeds on bentho- and mesopelagic crus- 
Table 4. Hoplostethus atlanticus. Percentage of total prey weight ( $\% \mathrm{~W})$ and frequency of occurrence $(\% \mathrm{~F})$ of prey items in the diet of adults during 1988. See Fig. 1 for abbreviations of sampling areas

\begin{tabular}{|c|c|c|c|c|c|c|c|c|c|c|c|c|}
\hline \multirow[t]{2}{*}{ Prey species } & \multicolumn{2}{|c|}{ GAB } & \multicolumn{2}{|c|}{ WTas } & \multicolumn{2}{|c|}{ ETas } & \multicolumn{2}{|c|}{ EBass } & \multicolumn{2}{|c|}{ NSW } & \multicolumn{2}{|c|}{ Total } \\
\hline & $\% \mathrm{~W}$ & $\% \mathrm{~F}$ & $\% W$ & $\% \mathrm{~F}$ & $\% W$ & $\% F$ & $\% \mathrm{~W}$ & $\% F$ & $\% \mathrm{~W}$ & $\% \mathrm{~F}$ & $\% W$ & $\% \mathrm{~F}$ \\
\hline Polychaeta & $<0.1$ & 0.4 & 0 & 0 & 0 & 0 & 0 & 0 & 0.5 & 2.2 & $<0.1$ & 0.3 \\
\hline \multicolumn{13}{|l|}{ Crustacea } \\
\hline Unidentified & 3.5 & 16.1 & 4.6 & 20.1 & 3.5 & 12.5 & 2.9 & 28.6 & 12.4 & 37.0 & 4.7 & 19.2 \\
\hline Copepoda & 0.1 & 0.9 & 0 & 0 & 2.8 & 2.3 & 0 & 0 & 0 & 0 & 0.3 & 0.6 \\
\hline \multicolumn{13}{|l|}{ Mysidacea } \\
\hline Unidentified & 2.0 & 9.4 & 0.9 & 3.4 & 3.6 & 6.8 & 0 & 0 & 1.3 & 2.2 & 1.5 & 5.6 \\
\hline Gnathophausia sp. & 4.9 & 1.8 & 1.2 & 0.9 & 7.4 & 6.8 & 40.1 & 28.6 & 7.6 & 4.3 & 4.2 & 2.5 \\
\hline Amphipoda & 5.4 & 27.4 & 0.3 & 2.7 & 0.9 & 8.0 & 0 & 0 & 0.1 & 2.2 & 1.8 & 11.3 \\
\hline \multicolumn{13}{|l|}{ Decapoda } \\
\hline \multicolumn{13}{|l|}{ Penaidae } \\
\hline Unidentified & 0 & 0 & 0.1 & 0.6 & 2.2 & 5.7 & 0 & 0 & 0 & 0 & 0.3 & 1.0 \\
\hline Sergestes (Sergestes) arcticus & 0.2 & 1.3 & 0.4 & 2.7 & 0 & 0 & 0 & 0 & 0 & 0 & 0.3 & 1.7 \\
\hline \multicolumn{13}{|l|}{ Caridae } \\
\hline Unidentified & 0.2 & 0.9 & 0.2 & 0.3 & 1.1 & 5.7 & 5.0 & 14.3 & 1.4 & 2.2 & 0.3 & 1.3 \\
\hline Pasiphae sp. & 1.5 & 4.0 & 3.6 & 7.3 & 2.3 & 4.5 & 0 & 0 & 0.9 & 2.2 & 2.7 & 5.5 \\
\hline Acanthephyra pelagica & 7.9 & 16.6 & 6.7 & 16.5 & 0 & 0 & 3.2 & 14.3 & 1.4 & 6.5 & 6.0 & 13.7 \\
\hline A. quadrispinosa & 0.1 & 0.4 & 0 & 0 & 0 & 0 & 0 & 0 & 0 & 0 & $<0.1$ & 0.1 \\
\hline Oplophorus novaezelandiae & 1.3 & 2.2 & 0.3 & 0.9 & 0 & 0 & 0 & 0 & 0 & 0 & 0.5 & 1.2 \\
\hline Pontophilus sp. & 0 & 0 & 0 & 0 & 0.3 & 1.1 & 0 & 0 & 0 & 0 & $<0.1$ & 0.1 \\
\hline \multicolumn{13}{|l|}{ Pisces } \\
\hline Gonostomatidae & 7.0 & 2.2 & 1.3 & 0.6 & 2.0 & 1.1 & 0 & 0 & 0 & 0 & 2.9 & 1.2 \\
\hline Unidentified & 21.7 & 18.4 & 44.8 & 40.9 & 22.6 & 23.9 & 48.8 & 42.9 & 50.8 & 50.0 & 36.3 & 32.1 \\
\hline \multicolumn{13}{|l|}{ Chauliodontidae } \\
\hline Chauliodus sloani & 24.1 & 8.5 & 5.2 & 1.5 & 10.2 & 3.4 & 0 & 0 & 0 & 0 & 10.9 & 3.9 \\
\hline \multicolumn{13}{|l|}{ Myctophidae } \\
\hline Unidentıfied & 2.6 & 1.8 & 4.0 & 4.3 & 8.6 & 5.7 & 0 & 0 & 2.9 & 6.5 & 3.8 & 3.8 \\
\hline Gymnoscopelus sp. & 0 & 0 & 0 & 0 & 3.4 & 2.3 & 0 & 0 & 0 & 0 & 0.3 & 0.3 \\
\hline Lampanyctus spp. & 0.6 & 0.9 & 0.2 & 0.3 & 0 & 0 & 0 & 0 & 0 & 0 & 0.3 & 0.4 \\
\hline Lampichthys sp. & 0 & 0 & 1.1 & 0.6 & 3.0 & 3.4 & 0 & 0 & 0 & 0 & 0.9 & 0.7 \\
\hline \multicolumn{13}{|l|}{ Paralepididae } \\
\hline Lestidiops pacifica & 0 & 0 & 0.9 & 0.3 & 0 & 0 & 0 & 0 & 0 & 0 & 0.5 & 0.1 \\
\hline \multicolumn{13}{|l|}{ Macrouridae } \\
\hline Lepidorhynchus denticulatus & 0 & 0 & 0 & 0 & 6.9 & 1.1 & 0 & 0 & 0 & 0 & 0.7 & 0.1 \\
\hline Coryphaenoides spp. & 0 & 0 & 1.9 & 0.9 & 8.0 & 2.3 & 0 & 0 & 0 & 0 & 1.8 & 0.7 \\
\hline \multicolumn{13}{|l|}{ Apogonidae } \\
\hline Epigonus lenimen & 0 & 0 & 0 & 0 & 11.1 & 8.0 & 0 & 0 & 0 & 0 & 1.1 & 1.0 \\
\hline \multicolumn{13}{|l|}{ Mollusca } \\
\hline Cephalopoda & 16.9 & 15.2 & 22.2 & 20.7 & 0.1 & 1.1 & 0 & 0 & 20.7 & 17.4 & 17.9 & 16.0 \\
\hline Total weight of prey $(\mathrm{g})$ & \multicolumn{2}{|c|}{3092.1} & 553 & 30.3 & 100 & 01.6 & & 0.8 & & 0.2 & 104 & 5.0 \\
\hline Total stomachs examined & 40 & & 64 & 99 & 26 & & 1 & 6 & & & & \\
\hline Stomachs with food present $(\%)$ & 223 & 55.6) & 328 & $(50.5)$ & 8813 & 33.5) & $7(4$ & 13.8) & 461 & 52.9] & 692 & 8.9) \\
\hline Mean of average stomach fullness & & & & & & & & & & & & \\
\hline per tow $\left(\mathrm{g} \mathrm{kg}^{-1}\right)$ & $5.56 \pm$ & 8.89 & $6.53=$ & \pm 6.45 & $2.73 \pm$ & \pm 1.97 & $11.13=$ & +14.35 & 4.55 & \pm 3.16 & 6.16 & 8.10 \\
\hline No. of tows & 5 & & 4 & 0 & 1 & 3 & & 2 & & 4 & & \\
\hline
\end{tabular}

tacea, fish and squid. Pasiphaeids, oplophorids and sergestids were the major decapod taxa consumed, as in New Zealand (Rosecchi et al. 1988). Kotlyar \& Lipskaya (1980) found pasiphaeids to be important in the diet of fish off the West Australian and Madagascar Ridges. The main families of the fish eaten by $H$. atlanticus were the chauliodontids and myctophids, as in the New Zealand study (Rosecchi et al. 1988). Squid comprised about $10 \%$ of the diet in terms of frequency of occurrence, which is consistent with previous reports (Kotlyar \& Lipskaya 1980, Rosecchi et al. 1988).

The diet of the orange roughy in the 3 areas and between the 2 years was broadly similar in terms of the overall ranking of prey groups. However, there were some significant differences in the incidence of particular prey groups in the diet among areas or between years. The dietary data suggest orange roughy are opportunistic feeders, so the variability in the data may 
Table 5. Hoplostethus atlanticus. Percentage of total prey weight (\% W) and frequency of occurrence (\% F) of prey items in the diet of adults during 1989. See Fig. 1 for abbreviations of sampling areas

\begin{tabular}{|c|c|c|c|c|c|c|c|c|c|c|}
\hline \multirow[t]{2}{*}{ Prey species } & \multicolumn{2}{|c|}{ GAB } & \multicolumn{2}{|c|}{ WTas } & \multicolumn{2}{|c|}{ ETas } & \multicolumn{2}{|c|}{ EBass } & \multicolumn{2}{|c|}{ Total } \\
\hline & $\% W$ & $\% \mathrm{~F}$ & $\% \mathrm{~W}$ & $\% \mathrm{~F}$ & $\% W$ & $\% \mathrm{~F}$ & $\% \mathrm{~W}$ & $\% \mathrm{~F}$ & $\% W$ & $\% F$ \\
\hline \multicolumn{11}{|l|}{ Crustacea } \\
\hline Unidentified & 3.8 & 12.5 & 2.8 & 9.0 & 2.8 & 11.1 & 0 & 0 & 3.0 & 10.5 \\
\hline \multicolumn{11}{|l|}{ Mysidacea } \\
\hline Unidentified & 0.4 & 3.4 & 0.1 & 2.8 & 0.1 & 1.2 & 0 & 0 & 0.2 & 2.5 \\
\hline Gnathophausia sp. & 2.1 & 2.3 & 2.1 & 2.1 & 1.5 & 3.7 & 0 & 0 & 1.9 & 2.5 \\
\hline Amphipoda & 1.2 & 13.6 & $<0.1$ & 0.7 & 0.3 & 4.9 & 0 & 0 & 0.4 & 5.4 \\
\hline \multicolumn{11}{|l|}{ Decapoda } \\
\hline \multicolumn{11}{|l|}{ Penaidae } \\
\hline Sergestes (Sergestes) arcticus & 0.5 & 2.3 & 0 & 0 & 0 & 0 & 0 & 0 & 0.1 & 0.6 \\
\hline \multicolumn{11}{|l|}{ Caridae } \\
\hline Unidentified & 0.3 & 2.3 & 0 & 0 & 0.4 & 1.2 & 0 & 0 & 0.2 & 1.0 \\
\hline Pasiphae spp. & 1.4 & 6.8 & 2.6 & 89.0 & 2.8 & 4.9 & 0 & 0 & 2.4 & 7.3 \\
\hline Acanthephyra pelagica & 2.7 & 10.2 & 1.9 & 4.8 & 0 & 0 & 0 & 0 & 1.6 & 5.1 \\
\hline A. quadrispinosa & 3.0 & 10.2 & 3.9 & 10.3 & 0.3 & 1.2 & 0 & 0 & 2.6 & 7.9 \\
\hline Oplophorus novaezelandiae & 3.9 & 1.1 & 0 & 0 & 2.6 & 7.4 & 0 & 0 & 1.7 & 2.2 \\
\hline \multicolumn{11}{|l|}{ Pisces } \\
\hline Unidentified & 11.7 & 22.7 & 51.6 & 56.6 & 48.0 & 49.4 & 0 & 0 & 41.0 & 45.4 \\
\hline Gonostomatidae & 2.1 & 1.1 & 0 & 0 & 0 & 0 & 0 & 0 & 0.5 & 0.3 \\
\hline \multicolumn{11}{|l|}{ Scopelasauridae } \\
\hline Scopelosaurus sp. & 2.2 & 1.1 & 0 & 0 & 0 & 0 & 0 & 0 & 0.5 & 0.3 \\
\hline \multicolumn{11}{|l|}{ Chauliodontidae } \\
\hline Chauliodus sloani & 10.2 & 3.4 & 2.0 & 0.7 & 7.0 & 3.7 & 0 & 0 & 5.4 & 2.2 \\
\hline \multicolumn{11}{|l|}{ Myctophidae } \\
\hline Unidentified & 0 & 0 & 3.6 & 3.4 & 3.5 & 1.2 & 0 & 0 & 2.7 & 1.9 \\
\hline Lampanyctus spp. & 0.7 & 1.1 & 3.9 & 4.1 & 0 & 0 & 0 & 0 & 2.0 & 2.2 \\
\hline Bathylagidae & 0 & 0 & 8.0 & 1.4 & 0 & 0 & 0 & 0 & 3.7 & 0.6 \\
\hline \multicolumn{11}{|l|}{ Macrouridae } \\
\hline Coryphaenoides spp. & 0 & 0 & 2.5 & 2.1 & 2.1 & 2.5 & 0 & 0 & 1.7 & 1.6 \\
\hline Other fish & 16.3 & 4.5 & 6.7 & 2.1 & 5.6 & 1.2 & 0 & 0 & 8.7 & 2.5 \\
\hline \multicolumn{11}{|l|}{ Mollusca } \\
\hline Cephalopoda & 36.8 & 20.5 & 8.3 & 11.0 & 23.0 & 11.1 & 100 & 100 & 19.4 & 13.7 \\
\hline \multicolumn{11}{|l|}{ Tunicata } \\
\hline Pyrosoma sp. & 0.7 & 3.4 & 0 & 0 & 0 & 0 & 0 & 0 & 0.2 & 1.0 \\
\hline Total weight of prey & \multicolumn{2}{|c|}{1280.9} & \multicolumn{2}{|c|}{2387.1} & \multicolumn{2}{|c|}{1439.9} & \multicolumn{2}{|c|}{41.0} & \multicolumn{2}{|c|}{5148.9} \\
\hline Total stomachs examined & & 8 & & 83 & & 49 & & 4 & & 34 \\
\hline Stomachs with food present $(\%)$ & 88 & $35.5)$ & 145 & $(30.0)$ & 811 & $32.5)$ & & $(25)$ & 315 & $32.0)$ \\
\hline Mean of average stomach fullness & & & & & & & & & & \\
\hline per tow $\left(\mathrm{g} \mathrm{kg}^{-4}\right)$ & 4.10 & $=9.89$ & 3.47 & \pm 3.63 & 3.82 & \pm 3.45 & 6.86 & \pm 9.70 & 3.83 & +7.00 \\
\hline No. of tows & & 1 & & 50 & & 20 & & 2 & & 43 \\
\hline
\end{tabular}

reflect spatial and temporal variation in the abundance of prey species.

As Hoplostethus atlanticus grows, fish become increasingly important in its diet, as Kotlyar \& Lipskaya (1980) and Rosecchi et al. (1988) reported. Similar shifts in the diet have been observed in other benthopelagic predators, such as Cyttus traversi and Helicolenus percoides (Blaber \& Bulman 1987), as well as in other fishes that are predominantly piscivorous as adults (e.g. Atlantic cod; Daan 1973). On the other hand, 3 benthopelagic macrourid species in Tasmanian waters (Coelorinchus spp. 2 and 4 and Lepidorhynchus denticulatus) do not exhibit this ontogenetic shift in dietary composition (Blaber \& Bulman 1987).
Squid appeared first in the diet of fish over $15 \mathrm{~cm}$. The proportion in the diet was at about the same level throughout the larger size classes. Squid was observed in the diet of orange roughy in the northeast Atlantic and off New Zealand in fish over $20 \mathrm{~cm}$ (Mauchline \& Gordon 1984, Rosecchi et al. 1988). The importance of squid in terms of proportion of the diet by weight is likely to be under-estimated since it is digested at a greater rate than fish or crustaceans. Often only the squid beaks remained in a stomach.

Resource-partitioning between adult and juvenile orange roughy is suggested by the observed inverse patterns of prey selection. Resource-partitioning among size classes of deepwater fish may be a mechan- 
Fig. 5. Hoplostethus atlanticus. Comparison of the diet of fish from an aggregation in the Great Australian Bight in 1988 and fish from the Bight area excluding the aggregation sites, by (a) prey weight and (b) frequency of occurrence of adults $(<30 \mathrm{~cm} \mathrm{SL})$ (a)
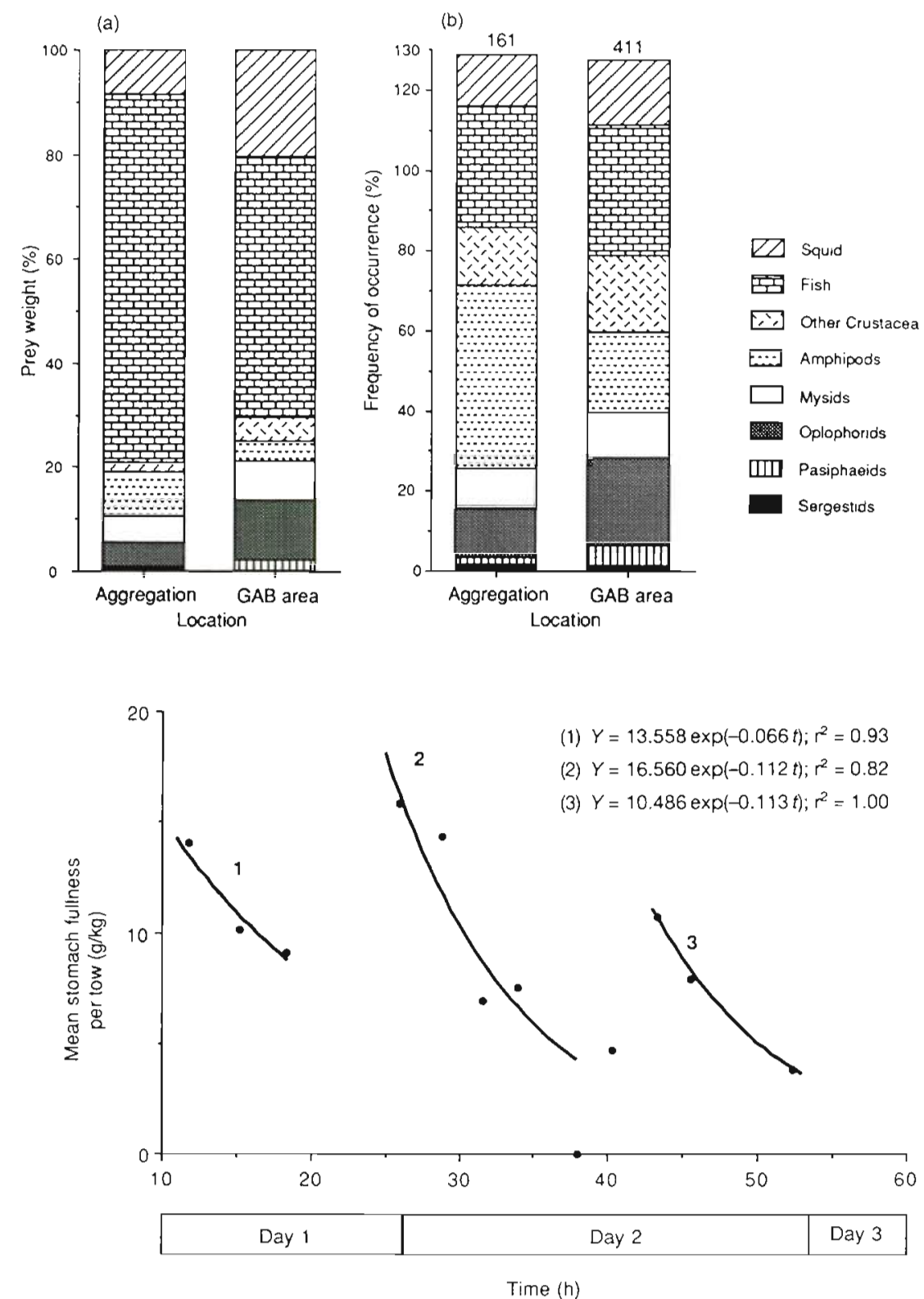

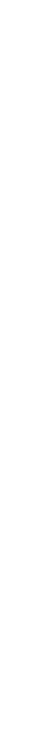

Fig. 6. Hoplostethus atlanticus. Mean stomach fullness per tow $\left(\mathrm{g} \mathrm{kg}^{-1}\right.$ body weight) of adults at the NSW sampling site over a $42 \mathrm{~h}$ period. Regressions were calculated for 3 consecutive periods when stomach fullness declined ism to reduce intra-specific competition at depths where prey are not abundant (Baird \& Hopkins 1981). Such a mechanism might be effective for a species such as Hoplostethus atlanticus which is the dominant component of the fish biomass at these depths in the region (Bulman et al. in press). However, hypotheses on competitive interactions are difficult to test with field survey data.

Diel feeding periodicity has not been previously reported for orange roughy (Rosecchi et al. 1988). It may have become apparent in our study due to our 10 fold larger sample size and concentrated sampling at a single site. Diel feeding periodicity is commonly reported for upper slope fishes that make diurnal feed- ing migrations (e.g. Kinzer \& Shulz 1985, Young \& Blaber 1986), but non-migratory slope fishes generally do not exhibit diel variation in feeding (Merrett \& Roe 1974, Macpherson 1981, Blaber \& Bulman 1987). There is no evidence that orange roughy migrates diurnally, but many of its prey apparently do, e.g. Chauliodus sloani (Morrow 1964), several species of Lampanyctus (Smith \& Heemstra 1986) and Acanthephyra pelagica and Sergestes (Sergestes) arcticus (Roe 1984). Orange roughy's crepuscular feeding pattern suggests that it is benefitting from migrators rising from mid-slope depths. Diel feeding periodicity was reported in the mesopelagic Valenciennellus tripunctulatus, which also does not itself migrate but feeds upon migrators 
(a) Adults

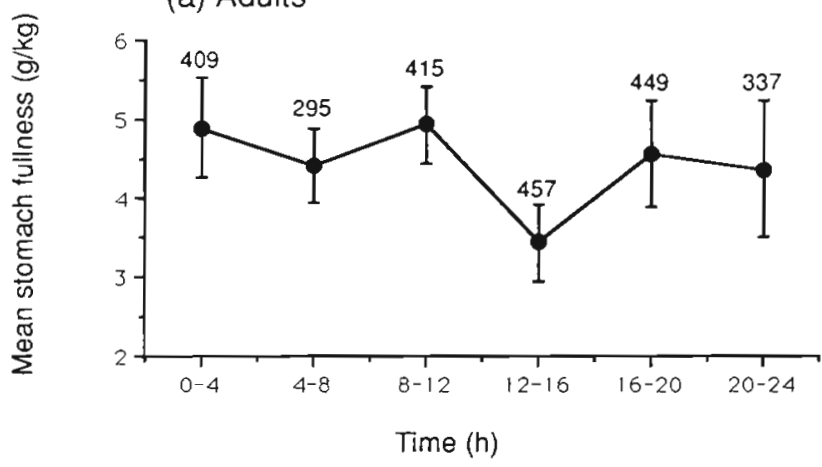

(b) Juveniles

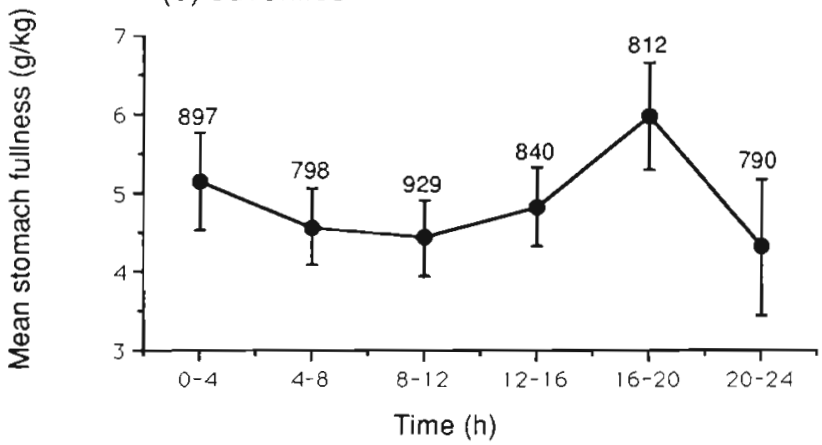

Fig. 7. Hoplostethus atlanticus. Mean stomach fullness per tow $\left(\mathrm{g} \mathrm{kg}^{-1}\right.$ body weight) over $4 \mathrm{~h}$ intervals for (a) adults (> $30 \mathrm{~cm} \mathrm{SL}$ ) and (b) juveniles ( $\leq 30 \mathrm{~cm}$ SL). Total numbers of fish for each time interval are above the standard error bars

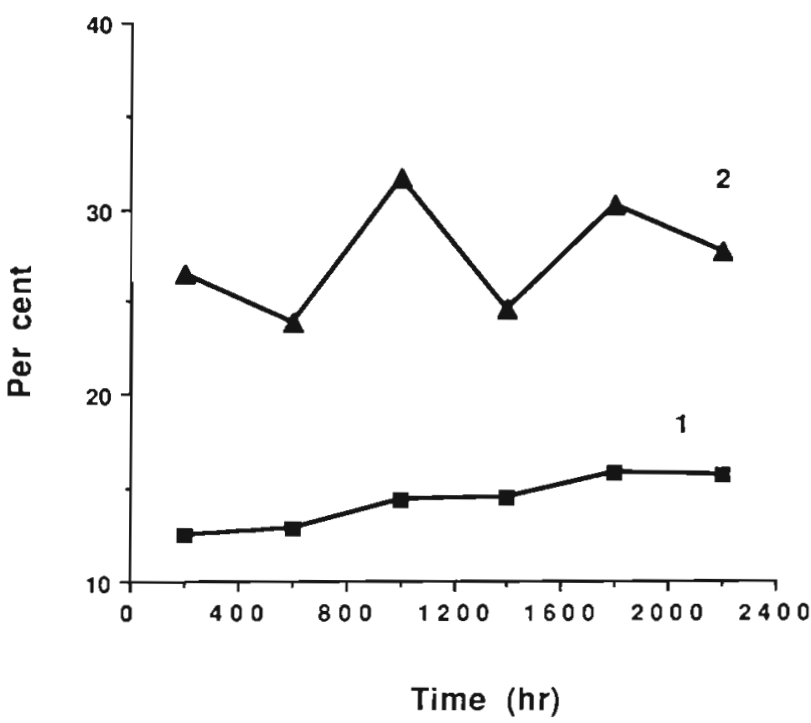

Fig. 8. Hoplostethus atlanticus. Proportion of juveniles $i \leq$ $30 \mathrm{~cm} \mathrm{SL}$ ) at early (stage 1) or advanced (stage 2) of digestion at $4 \mathrm{~h}$ intervals

that are available only during the day (Merret \& Roe 1974).

The high incidence of orange roughy with empty stomachs $(>50 \%)$ fits a general pattern noted for deepwater predator feeding on large invertebrates and fish (Legand \& Rivaton 1969, Merrett \& Roe 1974). These authors have speculated that this pattern indicates infrequent feeding or rapid digestion rates. The evacuation rate of benthopelagic predators has not been directly measured, but our estimate of gut residence time $(<1 \mathrm{~d})$ suggests that the rate of digestion is comparable to that of other cold-water piscivorous fishes (e.g. Atlantic cod; Jones 1978), but that feeding is infrequent. We found no evidence that orange roughy regurgitate their stomach contents. Orange roughy have an oil-filled swim bladder that is unaffected by pressure changes, which often cause an air-filled swim bladder to force out the stomach contents.

Our estimate of orange roughy food consumption $\left(0.91\right.$ and $1.15 \%$ body weight $\mathrm{d}^{-1}$ for juveniles and adults, respectively) is closer to estimates of the food consumption of several mesopelagic migrators $10.87 \%$ $\mathrm{d}^{-1}$ ), which are relatively active fishes, than to estimates for bathypelagic non-migrators $(0.68 \%)$ (Childress et al. 1980). This result was not expected, since these bathypelagic non-migrators are generally small (15 to $29 \mathrm{~cm}$ ), short-lived ( 4 to $8 \mathrm{yr}$ ) animals that exhibit rapid growth rates (Torres et al. 1979, Childress et al. 1980). Orange roughy, on the other hand, grows exceptionally slowly, maturing at $\sim 20 \mathrm{yr}$ at $\sim 30 \mathrm{~cm}$, and achieves a standard length of 45 to $50 \mathrm{~cm}$ at 50 to $100+$ yr (Mace et al. 1990, Fenton et al. 1991). The relatively high rate of food consumption and low growth rate of orange roughy have clear implications for estimates of the species' metabolism and growth efficiency.

There are no direct measurements of the metabolic rate of orange roughy, but metabolism can be estimated from data on their food consumption, growth, and reproduction, using the mass balance equation

$$
a R=G+T
$$

where $a$ is the coefficient of assimilation (which we assume equal to 0.8$), R$ is ration, $G$ represents growth and reproduction, and $T$ is metabolism. Available data indicate that the mean growth of orange roughy juveniles (10 to $20 \mathrm{yr}$ old) is $11 \% \mathrm{yr}^{-1}$ and of adults (20 to $50 \mathrm{yr}$ ) is $2.8 \% \mathrm{yr}^{-1}$ (Evans \& Wilson 1987, Mace et al. 1990). Annual reproductive effort of orange roughy is - $10 \%$ of body weight (Pankhurst \& Conrey 1987), so $G$ for adult roughy is ca $15 \% \mathrm{yr}^{-1}$ assuming that the energetic content of gonadal tissue is 1.2 that of somatic tissue (Ware 1980). Using our values for daily food consumption $(R)$, daily metabolism may be estimated to be $0.70 \%$ body weight for juveniles and $0.88 \%$ for adults. This translates to estimates of oxygen consumption for juveniles of $0.11 \mathrm{l} \mathrm{O}_{2} \mathrm{~kg}^{-1}$ wet wt h-1 and for adults of 0.14 , assuming conversions of $1750 \mathrm{kcal} \mathrm{kg}^{-1}$ wet wt, which is typical of mesopelagic fishes with a 
similar body composition to that of orange roughy (Table 6), and $4.63 \mathrm{kcal} \mathrm{l}^{-1} \mathrm{O}_{2}$ (Brett \& Groves 1979).

Based upon this exercise, metabolism of orange roughy is comparable to that of mesopelagic migratory species and approximately an order of magnitude higher than that of the bathypelagic non-migrators studied by Torres et al. (1979) $\left(\sim 0.01 \mathrm{l} \mathrm{O}_{2} \mathrm{~kg}^{-1}\right.$ wet wt $\mathrm{h}^{-1}$ ) (Table 6). Torres et al. (1979) apparently measured resting metabolic rates, whereas our estimates are of total field metabolism, so their values should be approximately doubled for comparison. [The in situ measurements of Smith \& Laver (1981) indicate that the active metabolism of bathypelagic non-migrators may be substantially higher than their resting metabolism (Table 6).] However, the apparent metabolism of orange roughy, which is a member of the mid-slope benthopelagic fauna sensu Marshall \& Merrett (1977), remains closer to that of mesopelagic migrators than of bathypelagic non-migrators. This is reasonable considering the ecology and composition of orange roughy. The proximate composition of fish is closely related to their metabolism (Torres et al. 1979). Orange roughy does not have the high water and reduced protein, lipid, and ash content that is typical of low-energy bathypelagic non-migrators (Table 6). Many bathypelagic species are not very active, whereas orange roughy may aggregate in areas of high near-bottom currents ( $\sim 25 \mathrm{~cm} \mathrm{~s}^{-1}$; V. Lyne, CSIRO, pers. comm.), and photographs indicate that they maintain a position oriented into the current (unpubl. data).

Related to their apparently high metabolism, the life history of orange roughy differs markedly from that of bathypelagic fishes. Bathypelagic non-migratory fishes typically have high rates of growth and growth efficiency, and non-asymptotic growth, apparently because they conserve energy through lower metabolism and reduced body structure and caloric content (Childress et al. 1980, Mauchline 1988). In contrast, growth in orange roughy is exceptionally slow, highly asymptotic, and very inefficient (about $4 \%$ ), apparently related to its relatively high metabolic costs (Table 6). Orange roughy is widely distributed in temperate midslope habitats of the southern oceans and North Atlantic, but is ecologically dominant in areas off Australia and New Zealand. Its dominance, which has led to the development of substantial fisheries, may be limited to regions of high currents and, we speculate, high energy input that can support its metabolic requirements. Clearly, the metabolic and gut evacuation rates of orange roughy should be measured directly, if possible, to test some of the assumptions underlying our preliminary energetic calculations for orange roughy. The biological oceanography of deepwater regions supporting this fish has yet to be characterized.

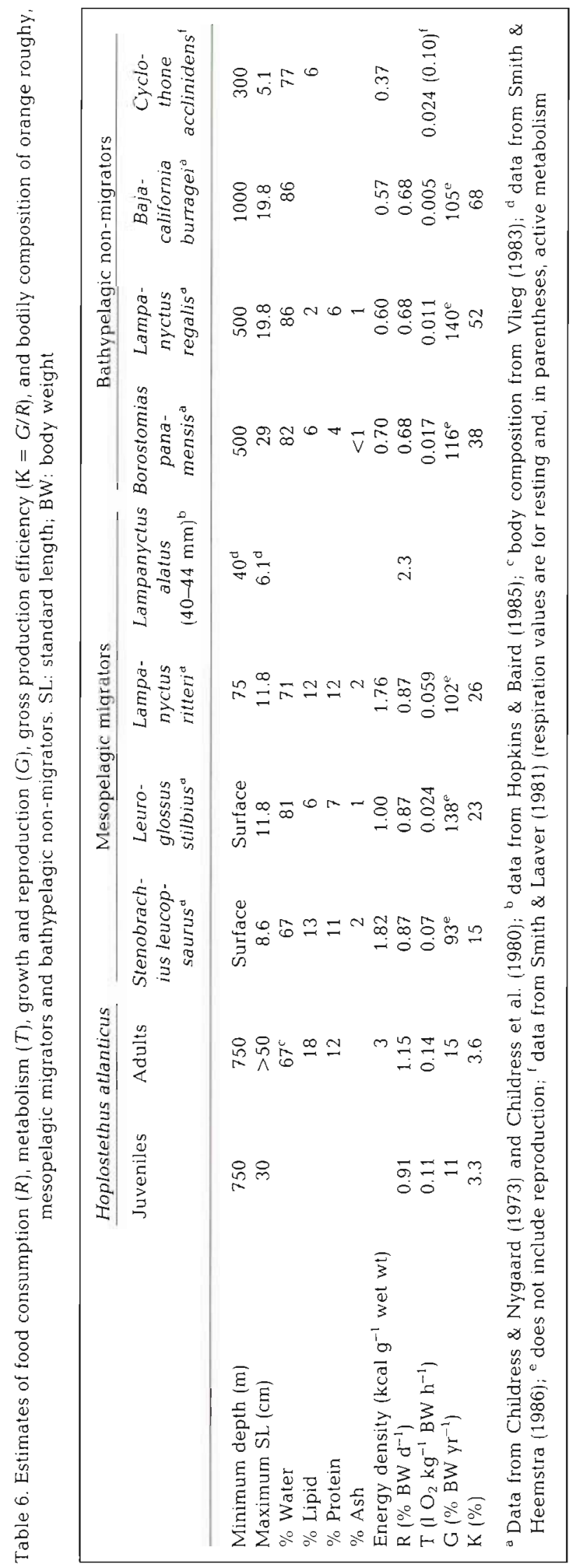


Acknowledgements. We thank all the staff of CSIRO who assisted in the research cruises and the master and crew of FRV 'Soela'. Many thanks to Ms S. E. Wayte for assistance with computing and statistics and to Ms K. Haskard for statistical advice. Dr K. Sainsbury provided invaluable advice and support throughout the project. Thanks also to Dr C. C. Lu for identifying the squid beaks, Dr J. Lowry for identifying the amphipods and Mr J. W. Young and Dr P. R. Last for identifying the Myctophidae and other fishes. This report presents results of part of a research project supported by FIRDC Grant $87 / 129$

\section{LITERATURE CITED}

Baird, R. C., Hopkins, T. L. (1981). Trophodynamics of the fish Valenciennellus tripunctulatus. III. Energetics, resources and feeding strategy. Mar. Ecol. Prog. Ser. 5: 21-28

Blaber, S. J. M., Bulman, C. M. (1987). Diets of fishes of the upper continental slope of eastern Tasmania: content, calorific values, dietary overlap and trophic relationships. Mar. Biol. 95: 345-356

Boisclair, D., Leggett, W C. (1988). An in situ experimental evaluation of the Elliot and Persson and the Eggers models for estimating fish daily ration. Can. J. Fish. Aquat. Sci. 45 138-145

Brett, J. R., Groves, T. D. D. (1979). Physiological energetics. In: Hoar, W. S., Randall, D. J. (eds.) Fish physiology, Vol. 8 Academic Press, New York, p. 279-351

Bulman, C. M., Wayte, S. E., Elliott, N. G. (in press). The 1988 and 1989 orange roughy surveys: abundance indices CSIRO Mar Lab. Rep. 215

Childress, J. J., Nygaard, M. (1973). The chemical composition of midwater fishes as a function of depth of occurrence off Southern California. Deep Sea Res. 20: 1093-1109

Childress, J. J., Taylor, S. M., Cailliet, G. M., Price, M. H (1980). Patterns of growth, energy utilization and reproduction in some meso- and bathypelagic fishes off Southern California. Mar. Biol. 61:27-40

Clarke, T. A. (1978). Diel feeding patterms of 16 species of mesopelagic fishes from Hawaiian waters. Fish. Bull. U.S 76: 495-513

Conover, W. J. (1971). Practical nonparametric statistics. John Wiley \& Sons, New York

Daan, N. (1973). A quantitative analysis of the food intake of the North Sea cod, Gadus morhua. Neth. J. Sea Res. 6: 479-517

Eggers, D. M. (1977). Factors in interpreting data obtained by diel sampling of fish stomachs. J. Fish. Res. Bd Can. 34: 290-294

Eggers, D. M. (1979). Comment on some recent methods for estimating food consumption by fish. J. Fish. Res. Bd Can. 36: 1018-1019

Elliot, J. M., Persson, L. (1978). The estimation of daily rates of food consumption for fish. J. Anim. Ecol. 47: 977-991

Evans, K., Wilson, M. A. (1987). A summary of orange roughy biological information: 1981-1985. Dept. of Sea Fisheries, Hobart, Tasmania

Fenton, G. E., Short, S. A., Ritz, D. A. (1991). Age determination of orange roughy, Hoplostethus atlanticus (Pisces: Trachichthyidae), using $210 \mathrm{~Pb} / 226 \mathrm{Ra}$ disequilibria. Mar. Biol. 109: 197-202

Gordon, J. D. M. Duncan, J. A. R. (1987). Aspects of the biology of Hoplostethus atlanticus and H. mediterraneus (Pisces: Berycomorphi) from the slopes of the Rockall Trough and the Porcupine Sea Bight (north-eastern Atlantic). J. mar. biol. Ass. U.K. 67. 119-133
Hopkins, T L., Baird, R. C. (1985). Aspects of the trophic ecology of the mesopelagic fish Lampanyctus alatus ( $\mathrm{Fa}$ mily Myctophidae) in the eastern Gulf of Maine. Biol. Oceanogr 3: 285-313

Jones, R. (1978). Estimates of the food consumption of haddock (Melanogrammus aeglefinus) and cod (Gadus morhua). J. Cons, int. Explor. Mer 38: 18-27

Kinzer, J., Schulz, K. (1985). Vertical distribution and feeding patterns of midwater fish in the central equatorial Atlantic. Mar. Biol. 85: 313-322

Kotlyar, A. N. (1980). Systematics and distribution of trachichthyid fishes (Beryciformes) of the Indian Ocean. Trudy Inst. Okeanol. Akad. Nauk SSR 110: 177-224

Kotlyar, A. N., Lipskaya, N. Y. (1980). Feeding of Hoplostethus atlanticus Collett (Trachichthyidae, Beryciformes). In: Fishes of the open ocean. Institute of Oceanology, Academy of Sciences USSR, Moscow, p. 89-93

Legand, M. Rivaton, J. (1969). Cycles biologiques des poissons mesopelagiques de l'est de l'ocean Indien. Troisieme note: action predatrice des poissons microectoniques. Cah. O.R.S.T.O.M., Sér. Oceanogr. $7: 29-45$

Mace, M. M., Fenaughty, J. M., Coburn, R. P., Doonan, I. J. (1990). Growth and productivity of orange roughy (Hoplostethus atlanticus) on the north Chatham Rise. N.Z. J. mar. Freshwat. Res. 24: 105-119

Macpherson, E. (1981). Resource partitioning in a Mediterranean demersal fish community. Mar. Ecol. Prog. Ser. 4: $183-193$

Marshall, N. B., Merrett, N. R. (1977). The existence of a benthopelagic fauna in the deep sea. Deep Sea Res. (Suppl.) 24: 483-497

Mauchline, J. (1988). Growth and breeding of meso- and bathypelagic organisms of the Rockall Trough, northeastern Atlantic Ocean and evidence of seasonality. Mar. Biol. 98: $387-393$

Mauchline, J., Gordon, J. D. M. (1984). Occurrence and feeding of berycomorphid and percomorphid teleost fish in the Rockall Trough. J. Cons. int. Explor Mer 41. $239-247$

Mauchline, J., Gordon, J. D. M. (1986). Foraging strategies of deep-sea fish. Mar. Ecol. Prog. Ser. 27: 227-238

Merrett, N. R., Roe, H. S. J. (1974). Patterns and selectivity in the feeding of certain mesopelagic fish. Mar. Biol. 28: $115-126$

Morrow, J. E. Jr. (1964). Family Chauliodontidae. In: Bigelow, H. B. (ed.) Fishes of the western North Atlantic. Memoir, Sears Foundation for Marine Research, No. 1, part 4. Yale University, New Haven, p. 274-289

Olson, R. J., Mullen, A. J. (1986). Recent developments for making gastric evacuation and daily ration determinations. Envir. Biol. Fish. 16: 183-191

Pankhurst, N. W., Conroy, A. M. (1987). Size-fecundity relationships in the orange roughy, Hoplostethus atlanticus. N.Z. J. mar. Freshwat. Res. 21: 295-300

Roe, H. S. J. (1984). Vertical migration and feeding of mysids and decapod crustacea. Prog. Oceanog. 13: 269-318

Rosecchi, E., Tracey, D. M., Webber, W R. (1988). Diet of orange roughy, Hoplostethus atlanticus (Pisces: Trachichthyidae) on the Challenger Plateau, New Zealand. Mar. Biol. 99: 293-306

Smith, K. L. Jr, Laver, M. B. (1981). Respiration of the bathypelagic fish Cyclothone acclinidens. Mar. Biol. 61. 261-266

Smith, M. M., Heemstra, P. C. (eds.) (1986). Smith's sea fishes. Springer-Verlag, Berlin

Tate, M. W., Clelland, R. C. (1957). Nonparametric and shortcut statistics in the social, biological and medical sciences. Interstate Printers and Publishers, Danville, Illinois 
Torres, J. J., Belman, B. W., Childress, J. J. (1979). Oxygen consumption rates of midwater fishes as a function of depth of occurrence. Deep Sea Res. 26: 185-197

Vlieg, P. (1983). Transmission oil from fish? Catch (N.Z. Minist. Agric. Fish.) 10:21-22

This article was presented by R. L. Haedrich, St. John's, Nfld, Canada
Ware, D. M. (1980). Bioenergetics of stock and recruitment. Can. J. Fish. Aquat. Sci. 37: 1012-1024

Young, J. W., Blaber, S. J. M. (1986). Feeding ecology of three species of midwater fishes associated with the continental slope of eastern Tasmania, Australia. Mar. Biol. 93: 147-156

Manuscript first received: February 11, 1991

Revised version accepted: March 19, 1992 